\title{
PERIBAHASA MINANGKABAU BERLEKSIKON PERALATAN DAPUR TRADISIONAL
}

\author{
Annisa Ulvia ${ }^{1^{*}}$, Lindawati ${ }^{2}$, Bahren $^{3}$ \\ annisaulvia1996@gmail.com* \\ Fakultas Ilmu Budaya Universitas Andalas ${ }^{1,2,3}$
}

\begin{abstract}
ABSTRAK
Artikel ini mendeskripsikan peribahasa Minangkabau yang mengandung leksikon peralatan dapur tradisional. Leksikon peralatan dapur diperoleh melalui metode yang digunakan saat penyediaan data leksikon adalah metode simak, yaitu dilakukan dengan menyimak penggunan bahasa oleh informan dalam wawancara, Teknik dasar yang digunakan adalah teknik sadap. Sementara teknik lanjutannya yaitu teknik simak libat cakap. Kemudian dalam penelitian ini juga menggunakan teknik catat. Sementara itu, peribahasa diperoleh melalui buku Peribahasa Minangkabau oleh Anas Nafis. Hasil analisis menunjukkan tiga puluh empat leksikon peralatan dapur tradisional di Minangkabau, dua puluh leksikon termasuk ke dalam morfem bebas dan lima belas leksikon termasuk ke dalam frasa nominal. Makna yang ditemukan dalam penelitian mengenai peralatan dapur tradisional di Minangkabau ini adalah makna leksikal dan diperoleh tiga puluh peribahasa yang mengandung peralatan dapur tradisional.
\end{abstract}

Kata-kata kunci: Peribahasa, Minangkabau, Leksikon, Alat Dapur.

\section{MINANGKABAU PROVERBS LEXICED TRADITIONAL KITCHEN EQUIPMENT}

\begin{abstract}
This article describes Minangkabau proverbs that contain a lexicon of traditional kitchen utensils. The kitchen utensil lexicons are obtained through the method used when providing lexicon data is the observation method, which is done by listening to the use of language by the informant in the interview. The basic technique used is the tapping technique. The advanced technique is the technique of engaging listening proficiently. Then in this study also used the notetaking technique.

Meanwhile, proverbs were obtained through the Peribahasa Minangkabau book by Anas Nafis. The results show that thirty-four lexicons of traditional kitchen utensils in Minangkabau, twenty lexicons are included in the free morpheme, and fifteen lexicons are included in the nominal phrase. The meaning found in the research on traditional kitchen utensils in Minangkabau is lexical, and thirty proverbs contain traditional kitchen utensils.
\end{abstract}

Keywords: Proverbs, Minangkabau, Lexicon, Kitchen Utensil.

Jurnal Elektronik WACANA ETNIK - Vol 8 No 1 2019, (1 - 11) p ISSN 2089-8746, e ISSN 2302-7142

Submit: Februari 2019. Diterima: Maret 2019. Publikasi: April 2019. 


\section{PENGANTAR}

Seiring perkembangan zaman dan teknologi maka berkembang pulalah cara pikir manusia. Segala yang bersifat tradisional sudah berangsur-angsur ditinggalkan. Salah satu contohnya adalah peralatan dapur. Peralatan dapur merupakan berbagai benda atau perkakas yang digunakan untuk mengolah suatu bahan agar menjadi masakan. Peralatan dapur tradisional dari satu daerah ke daerah lain di Minangkabau memiliki kesamaan fungsi meskipun dalam penyebutan nama terdapat perbedaan. Selain digunakan sebagai alat untuk mengolah berbagai jenis makanan, peralatan dapur tradisional juga menyimpan berbagai unsur kebudayaan, maksudnya ada ungkapan-ungkapan yang dibuat berdasarkan leksikon peralatan dapur tradisional. Peralatan dapur dapat menggali pemikiran kebudayaan yang tersimpan melalui peribahasa. Peribahasa atau kiasan merupakan salah satu cara berbahasa yang meninggikan nilainilai kemanusiaan karena peribahasa atau kiasan tersebut dapat dipakai untuk menyatakan sesuatu secara sopan. Dengan cara berkias, lawan tutur tidak merasa dipojokkan seketika. Bahasa kias dapat pula menjaga harga diri lawan tutur jika suatu maksud atau pesan ingin disampaikan di depan umum. Pesan yang ingin disampaikan disembunyikan dibalik lambang kias tersebut (Oktavianus,2012:66).

\section{Balago sanduak jo pariyuak alah biaso.}

Berlaga/bertemu sendok dengan periuk sudah biasa.

Dari ungkapan di atas, kita tahu bahwa sanduak 'sendok' merupakan alat yang digunakan untuk mengaduk nasi setelah matang, sedangkan pariuak 'periuk' adalah alat yang digunakan untuk memasak beras hingga menjadi nasi. Saat mengaduk nasi pastilah terjadi persentuhan antara sanduak dan pariuak. Sanduak dan pariuak selain sebagai leksikon peralatan dapur juga dapat menciptakan berbagai ungkapan atau peribahasa seperti yang terdapat dalam contoh tersebut. Balago sanduak jo pariuak alah biaso. Ungkapan dengan menggunakan sanduak dan pariuak pada peribahasa tersebut menggambarkan kehidupan dalam suatu rumah tangga. Ungkapan tersebut menyatakan bahwa cek cok atau pertengkaran antara suami dengan istri merupakan hal yang sudah biasa terjadi. Oleh karena itu, leksikon peralatan dapur tradisional perlu diteliti lebih lanjut karena selain untuk mempertahankan bahasa Minangkabau, peralatan dapur tradisional juga menyimpan pemikiran kebudayaan Minangkabau yang harus dilestarikan.

\section{KERANGKA TEORI DAN METODE}

Leksikologi dan leksikografi adalah dua buah kegiatan dalam bidang linguistik yang saling berkaitan. Yang pertama, leksikologi, bersifat kajian ilmiah teoretis, sedangkan leksikografi, lebih bersifat kegiatan praktis, meskipun juga tidak terlepas dari ilmiah teoretis. Urutan kegiatan keduanya tidak bisa dibalik karena tidak mungkin bisa dilakukan kegiatan leksikografi tanpa terlebih dahulu dilakukan kajian leksikokologi (Chaer, 2007:1). Leksikologi merupakan bidang ilmu yang mengambil leksikon sebagai objek kajiannya. Dalam leksikologi, butir-butir leksikal suatu bahan dikaji asalusulnya, bentuk dan pembentukannya, maknanya, penggunaannya, aspek bunyi dan ejaannya. Pakar yang melakukan kajian leksikologi ini lazim disebut leksikolog. Lalu, kemudian hasil kajian leksikologi ini ditulis dan disusun secara alfabetis, maka bidang kegiatannya sudah termasuk kegiatan leksikografi.

Kata leksikon itu sendiri berasal dari bahasa Yunani, lexicon yang artinya "kata" atau "ucapan" (Chaer, 2007: 5). Leksikon adalah komponen bahasa yang memuat semua informasi tentang makna dan pemakaian kata dalam 
bahasa. Leksikon merupakan kekayaan kata yang dimiliki seorang pembicara, penulis, atau suatu bahasa, kosakata, perbendaharaan kata. Leksikon juga merupakan daftar kata yang disusun seperti kamus, tetapi dengan penjelasan yang singkat dan praktis (Kridalaksana, 2008: 142).

Metode yang digunakan saat penyediaan data leksikon adalah metode simak, yaitu dilakukan dengan menyimak penggunan bahasa (Sudaryanto, 1993:133). Teknik dasar yang digunakan adalah teknik sadap. Teknik sadap dilakukan pada saat pengambilan dokumentasi dari peralatan dapur tradisional. Sementara teknik lanjutannya yaitu teknik simak libat cakap. Kemudian dalam penelitian ini juga menggunakan teknik catat. Metode yang digunakan dalam penyediaan data mengenai peribahasa juga metode simak. Dalam penelitian ini penulis menyimak penggunaan peribahasa mengenai peralatan dapur tradisional dalam buku peribahasa yang ada. Teknik dasar yang digunakan adalah teknik sadap dengan teknik Simak Bebas Libat Cakap dan teknik catat sebagai teknik lanjutan.

Populasi yang diambil dalam penelitian ini adalah leksikon peralatan dapur tradisional di Minangkabau, sedangkan sampelnya yaitu leksikon peralatan dapur tradisional di Jorong Galagah, Kenagarian Alahan Panjang, Kabupaten Solok dan Jorong Silabu, Nagari Parambahan, Kabupaten Tanah Datar sebagai daerah darek Minangkabau, dan Kelurahan Karan Aur, Pariaman sebagai daerah rantau. Alasan penulis mengambil tiga lokasi tersebut adalah dimaksudkan agar ketiga daerah tersebut dapat mewakili daerah darek dan rantau yang ada di Minangkabau.

\section{HASIL DAN PEMBAHASAN}

Peralatan dapur tradisional merupakan salah satu bentuk kebudayaan daerah. Dinamakan peralatan dapur karena lokasi penggunaannya berada didapur, yaitu untuk mengolah berbagai jenis bahan makanan yang mentah menjadi makanan yang siap disajikan. Peralatan dapur tradisional dari satu daerah ke daerah lainnya di Minangkabau memiliki kesamaan bentuk dan fungsi, walaupun ada beberapa perbedaan dalam hal penamaan. Perbedaan penamaan tersebut terjadi karena dialek dari masing-masing daerah di Minangkabau berbeda. Perlu disampaikan di sini bahwa artikel ini tidak menampilkan semua temuan data yang diperoleh karena pertimbangan ruang yang terbatas.

\section{Balango}

Balango merupakan kata yang terdiri atas satu morfem dan belum mengalami proses perubahan morfologis atau penambahan imbuhan. Istilah balango termasuk ke dalam morfem bebas.

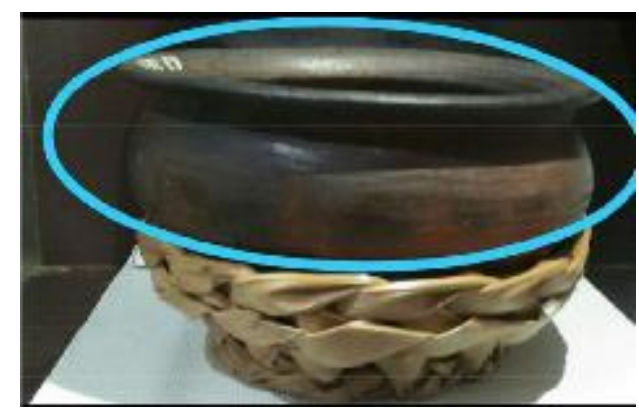

GAMBAR 1. Balango 
Balango (n) 'belanga' merupakan sejenis periuk dari tanah (Yos, 2015: 48). Masyarakat di Jorong Galagah dan di Kelurahan Karan Aur menyebutnya balango sedangkan masyarakat di Jorong Silabu, Nagari Parambahan menyebutnya pariuak tanah. Balango merupakan salah satu peralatan dapur tradisional yang terbuat dari tanah liat dan memiliki ukuran yang bervariasi, ada yang kecil, menengah, dan besar sesuai dengan kebutuhan pemakainya. Balango berbentuk bundar dengan mulut besar, memiliki bibir dan melengkung di bagian atas.

Kegunaan dari balango juga beragam, yaitu digunakan sebagai tempat untuk membuat gulai, membuat asam padeh, merebus makanan atau sayuran, membuat pangek, dan pada zaman dahulu balango juga digunakan sebagai alat untuk membuat kue panggang sebelum adanya alat pemanggang modern seperti oven, yaitu dengan cara memasukkan pasir ke dalam balango hingga setengah dari balango tersebut berisi pasir, kemudian letakkan cetakan kue panggang di atas pasir tersebut, dan letakkan balango di atas tungku. Tutup bagian atas belanga menggunakan seng dan beri bara api di atas seng tersebut.

Mamapeh dalam balango (Nafis, 1996: 51)

Mamapeh dalam balango merupakan salah satu peribahasa yang berkaitan dengan leksikon peralatan dapur tradisional, yaitu balango. Peribahasa ini memiliki makna yang konotatif, terdapat makna kias yang terkandung di dalamnya. Mamapeh merupakan kegiatan memancing ikan Mamapeh biasanya dilakukan dikolam ikan, namun pada peribahasa di atas mamapeh dilakukan di dalam balango. Balango pada peribahasa ini diibaratkan seperti kuali berisi ikan yang sudah dimasak. Seseorang yang mamapeh dalam balango hanya menikmati hasilnya saja tanpa ikut bersusah payah untuk mendapatkannya. Peribahasa ini berarti mengibaratkan seseorang yang mencari keuntungan dari kerabatnya sendiri.

Asam digunuang, Ikan dilauik, batamu juo dalam balango (Nafis, 1996: 51)

Ikan dilauik, asam digunuang, batamu juo dalam balango merupakan salah satu peribahasa yang berkaitan dengan leksikon peralatan dapur tradisional, yaitu balango. Peribahasa ini memiliki makna yang konotatif, terdapat makna kias yang terkandung di dalamnya. Ikan pada peribahasa di atas diumpamakan seperti seorang laki-laki, asam diumpamakan sebagai seorang wanita dan balango diumpamakan seperti sebuah rumah tangga, laut dan gunung diibaratkan sebagai sebuah tempat yang saling berjauhan. Peribahasa tersebut berarti dua insan lawan jenis, walaupun berbeda negeri asal namun tetap bisa hidup berumah tangga dalam satu ikatan perkawinan.

\section{Cerek}

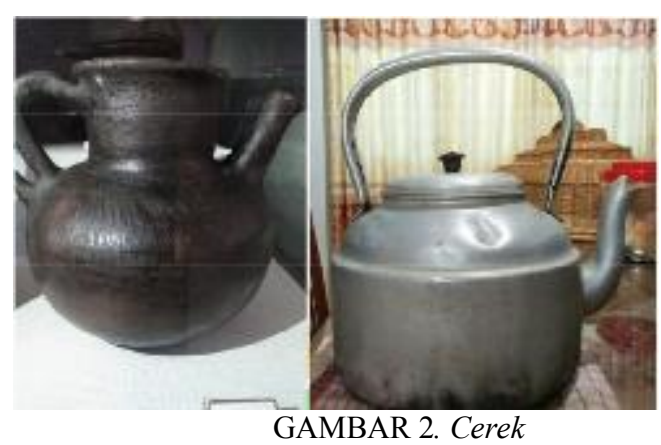


Cerek merupakan kata yang berbentuk monomorfemis karena terdiri dari satu morfem saja. 1stilah cerek termasuk kedalam morfem bebas karena cerek dapat berdiri sendiri sebagai sebuah kata tanpa dibantu oleh morfem lain dan tanpa morfem lain. Istilah cerek ini tetap memiliki arti tersendiri berdasarkan referennya.

Cerek (n) tempat air minum yang mempunyai cerat atau moncong (Saydam, 2004:71). Masyarakat di Jorong Galagah, masyarakat di Kelurahan Karan Aur dan masyarakat di Jorong Silabu, Nagari Parambahan menamakan benda ini dengan nama cerek. Cerek merupakan peralatan dapur yang berfungsi sebagai wadah penyimpan air minum. Pada zaman dahulunya cerek terbuat dari tanah liat. Namun, pada zaman sekarang sudah tergantikan dengan cerek yang terbuat dari plastik maupun aluminium. Cerek mirip seperti bejana yang salah satu sisinya diberi mulut sebagai tempat untuk keluar air. Cerek dilengkapi dengan tangkai sebagai pegangan ketika digunakan.

\section{Elok mancerek dari mancawan (Nafis, 1996: 94)}

Elok mancerek dari mancawan merupakan salah satu peribahasa yang berkaitan dengan leksikon peralatan dapur tradisional, yaitu cerek. Peribahasa ini memiliki makna yang konotatif, terdapat makna kias yang terkandung di dalamnya. Mancerek merupakan salah satu kegiatan mencurahkan air dari cerek. Mancerek diibaratkan seperti seseorang yang bersikap seperti cerek, yaitu suka memberi, sedangkan mancawan diibaratkan seperti seseorang yang bersikap seperti cawan, yaitu hanya suka menampung atau menerima saja. Peribahasa di atas berarti lebih baik memberi daripada hanya menerima saja.

\section{Katidiang}

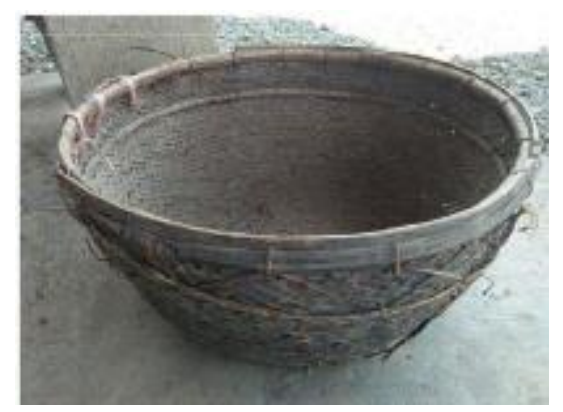

GAMBAR 3. Katidiang

Katidiang rnerupakan k.ata yang terdiri atas satu morfern dan belurn mengalami proses perubahan morfologis atau penambahan imbuhan. Istilah katidiang termasuk ke dalam morlem bebas. Katidiang (n) : 'ketiding, bakul dari anyaman bambu' (Saydam , 2004:185). Masyarakat di Jorong Galagah dan masyarakat di Jorong Silabu Nagari Parambahan menamakan benda ini katidiang. Katidiang merupakan peralatan dapur tradisional yang terbuat dari anyaman bambu, berbentuk bundar, dengan mulut lebar. Bagian tepinya diberi bingkai dari rotan yang sudah dianyam untuk menguatkan sewaktu diangkat. Katidiang berfungsi sebagai alat untuk meniriskan beras yang akan ditumbuk.

Bak ula dalam katidiang (Nafis, 1996: 229)

Bak ula dalam katidiang merupakan salah satu peribahasa yang berkaitan dengan leksikon peralatan dapur tradisional, yaitu katidiang. Peribahasa ini memiliki makna yang konotatif, terdapat makna kias yang terkandung di dalamnya. Bak ula dalam katidiang, ular jika dimasukkan ke dalam sebuah bakul, tentu ia akan berputar-putar saja. 
Pada peribahasa tersebut ular diumpamakan seperti seorang manusia yang sedang sakit pinggang, kerjanya hanya berputar- putar dan menggeliat-liat saja menahan rasa sakit.

Pinggang sariang bak katidiang (Nafis, 1996: 229)

Pinggang sariang bak katidiang merupakan salah satu peribahasa yang berkaitan dengan peralatan dapur tradisional yaitu katidiang. Peribahasa ini memiliki makna yang konotatif, terdapat makna kias yang terkandung di dalamnya. Peribahasa tersebut merupakan sebuah ejekan untuk seseorang yang mempunyai pinggang yang besar.

\section{Kuali}

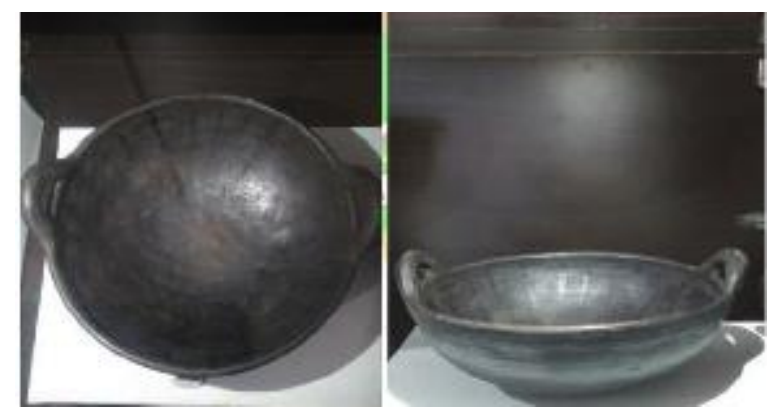

GAMBAR 4. Kuali

Istilah kuali merupakan kata yang berbentuk monomorfemis karena terdiri dari satu morfem saja. Istilah kuali termasuk ke dalam morfem bebas, karena istilah kuali ini dapat berdiri sendiri sebagai sebuah kata tanpa dibantu oleh morfem lain dan tanpa morfem lai $n$ istilah kuali ini tetap memiliki arti tersendiri berdasarkan referennya.

Kuali (n) ‘tempat menggoreng, terbuat dari besi atau aluminium’ (Yos, 2005 :223). Masyarakat di Jorong Galagah, Kenagarian Alahan Panjang, masyarakat di Kelurahan Karan Aur dan masyarakat di Jorong Silabu, Nagari Parambahan menamakan benda ini dengan nama kuali. Kuali merupakan salah satu peralatan dapur tradisional yang memegang peranan yang sangat penting.

\section{Sarupo talingo kuali.}

Sarupo talingo kuali merupakan salah satu peribahasa yang berkaitan dengan peralatan dapur tradisional yaitu kuali. Peribahasa ini memiliki makna yang konotatif. Telinga adalah alat indra yang digunakan untuk mendengar, namun talingo kuali hanya berfungsi untuk menggantung kuali setelah selesai digunakan. Jadi, peribahasa tersebut mengiaskan seseorang yang mempunyai telinga, namun telinga tersebut tidak digunakan untuk mendengar. Peribahasa tersebut berarti diibaratkan kepada seseorang yang tuli, tidak mau mendengarkan perkataan orang lain.

Tatungkuik bak kuali (Nafis, 1996: 241)

Tatungkuik bak kuali merupakan salah satu peribahasa yang berkaitan dengan peralatan dapur tradisional yaitu kuali. Peribahasa ini memiliki makna yang konotatif. Kuali yang dimaksud dalam peribahasa ini adalah kuali basi yaitu berwarna hitam pekat. Peribahasa tersebut mengibaratkan kepada seseorang yang memiliki kulit gelap, hitam pekat seperti kuali. 
Kuali merupakan peralatan dapur yang digunakan sebagai alat untuk menggoreng, menumis, membuat sayur dan lain sebagainya. Kuali terdiri dari beberapa jenis, ada yang terbuat dari tanah liat, dari besi maupun dari aluminium. Kuali yang terbuat dari tanah liat saat sekarang ini sudah tidak ditemukan lagi. Namun kuali dari besi keberadaannya masih ada, namun penggunaannya sangat dibatasi, seperti salah satunya digunakan untuk membuat rendang, galamai maupun wajik. Kuali jenis ini dinamakan dengan kancah. Kancah tidak memiliki telinga pada kedua sisinya, kancah terbuat dari besi, berwarna hitam, lebih berat dan lebih besar jika dibandingkan dengan kuali yang terbuat dari tanah liat maupun aluminium. Untuk memasak sehari-hari, masyarakat lebih suka menggunakan kuali yang terbuat dari aluminium, karena lebih ringan. Kuali berbentuk setengah lingkaran, cekung, mirip dengan parabola. Di bagian pinggirnya dilengkapi dengan dua telinga, yang difungsikan sebagai tempat memegang sewaktu digunakan, namun telinga pada kuali juga dapat digunakan untuk menggantung kuali tersebut pada paku setelah digunakan. Ukuran dari kuali bermacam-macam, sesuai dengan kebutuhan para penggunanya.

\section{Ladiang}

Istilah ladiang merupakan kata yang berbentuk monomorfemis karena terdiri dari satu morfem saja. Ladiang termasuk ke dalam morfem bebas karena ia dapat berdiri sendiri s bagai sebuah kata tanpa dibantu oleh morfem lain dan tanpa morfem lain istilah ladiang ini tetap memiliki arti tersendiri berdasarkan referennya.

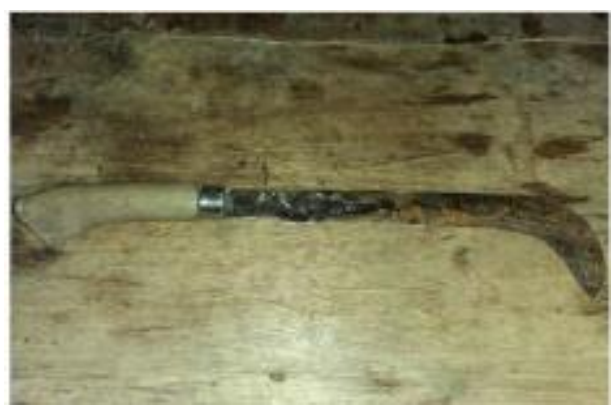

GAMBAR 5. Ladiang

Lading (n) 'lading, parang, golok', (Saydam, 2004). Masyarakat di Jorong Galagah, di Keluraban Karang Aur dan di Jorong Silabu, Nagari Parambahan menamakan benda ini dengan nama ladiang. Ladiang merupakan peralatan dapur tradisional yang menyerupai pisau, namun memiliki ukuran dan panjang yang lebih besar dari pisau. Ladiang terbuat dari besi yang ujungnya sedikit dilekukkan agar memudahkan para penggunanya untuk memotong sesuatu. Pada ujung besi diberi tangkai yang terbuat dari kayu yang sudah dihaluskan dan dibuat sedikit melengkung di bagian pangkal. Ladiang memiliki bermacam fungsi seperti untuk memotong kayu bakar, membelah kayu, untuk memisahkan kelapa dari sabutnya, untuk membelah kelapa yang akan dikukur, untuk memotong bahan-bahan makanan yang sedikit lebih keras yang tidak bisa dipotong menggunakan pisau, dan lain sebagainya.

Pungguang ladiang kok diasah tajam juo (Nafis, 1996: 264)

Pungguang ladiang kok diasah tajam juo merupakan salah satu peribahasa yang berkaitan dengan peralatan dapur tradisional, yaitu ladiang. Ladiang adalah alat yang digunakan untuk memotong atau membelah bahan-bahan 
masakan. Ladiang sama seperti pisau, terdiri dari dua buah sisi, sisi yang tajam dan yang tumpul. Pada peribahasa ini, bagian yang tajam dari ladiang diibaratkan kepada seseorang yang pandai, sedangkan bagian yang tumpul diibaratkan kepada seseorang yang bodoh. Pungguang ladiang 'punggung lading' merupakan bagian yang tumpul namun jika sering diasah maka lama-kelamaan akan tajam. Begitu pun dengan manusia yang kurang pandai atau bodoh, jika selalu diasah dengan cara belajar dan selalu mencari ilmu, maka akan pandai juga.

Ladiang indak tau dimajanyo (Nafis, 1996: 263)

Ladiang indak tau dimajanyo merupakan salah satu peribahasa yang berkaitan dengan peralatan dapur tradisional, yaitu ladiang. Ladiang maja 'tumpul' dalam peribahasa ini diibaratkan sebagai seorang manusia yang tidak memiliki kemampuan apa-apa. Peribahasa ini berarti seseorang yang tidak menyadari keadaan dirinya sendiri.

Ladiang tajam sabalah (Nafis, 1996: 263)

Ladiang tajam sabalah merupakan salah satu peribahasa yang berkaitan dengan peralatan dapur tradisional, yaitu ladiang. Ladiang sama seperti pisau memiliki dua buah sisi. Sisi yang satu tajam dan sisi yang lainnya tumpul. Dalam peribahasa ini sisi yang tajam diibaratkan sebagai seorang manusia yang suka memberi begitu pun sebaliknya. Jadi, peribahasa tersebut dikiaskan pada seseorang yang maunya menerima saja, tetapi enggan memberi.

\section{Pariuak nasi}

Pariuak nasi termasuk dalam jenis frasa nomina diikuti nomina karena terdiri atas nomina sebagai unsur pokoknya yang diikuti oleh nomina lain sebagai atributnya. Pariuak (n) 'periuk' (Saydam, 2004:286). Masyarakat di Jorong Galagah, Kenagarian Alahan Panjang menamakan benda ini dengan pariuak nasi, masyarakat di Kelurahan Karan Aur dan masyarakat di Jorong Silabu, Nagari Parambahan menamakan benda ini dengan nama pariuak.

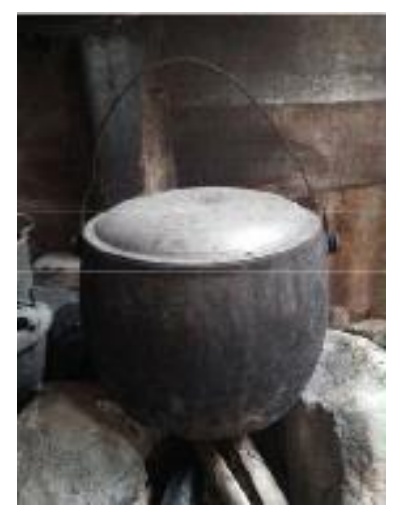

GAMBAR 6. Pariuak nasi

Pariuak nasi merupakan periuk yang digunakan untuk memasak nasi. Periuk ini berbentuk bundar dan terbuat dari besi atau aluminium. Pada bagian atasnya terdapat penutup dan dilengkapi dengan besi yang dibengkokkan dan ditempelkan pada kedua sisi periuk sebagai pegangan ketika pengguna hendak memindahkan periuk dari satu tempat ke tempat lain. Ukuran dari periuk ini juga beragam, sesuai dengan kebutuhan penggunanya.

Gadang pariuak, gadang pulo karaknyo (Nafis, 1996: 364) 
Gadang pariuak, gadang pulo karaknyo merupakan salah satu peribahasa yang berkaitan dengan leksikon peralatan dapur tradisional, yaitu pariuak. Pariuak dalam peribahasa ini diibaratkan pada penghasilan seseorang dan karak pada ungkapan tersebut diibaratkan sebagai pengeluaran. Jika penghasilan besar, tentu pengeluaran juga besar.

Balago sanduak jo pariuak alah biaso (Nafis, 1996: 431)

Balago sanduak jo pariuak alah biaso merupakan salah satu peribahasa yang berkaitan dengan peralatan dapur tradisional, yaitu sanduak dan pariuak. Dari ungkapan tersebut, kita tahu bahwa sanduak merupakan alat yang digunakan untuk mengaduk nasi setelah matang, sedangkan pariuak adalah alat yang digunakan untuk memasak beras hingga menjadi nasi. Saat mengaduk nasi pastilah terjadi persentuhan antara sanduak dan pariuak. Ungkapan dengan menggunakan sanduak dan pariuak pada peribahasa tersebut menggambarkan kehidupan dalam suatu rumah tangga. Ungkapan tersebut menyatakan bahwa cekcok atau pertengkaran antara suami dengan istri merupakan hal yang sudah biasa terjadi.

\section{Tungku}

Istilah tungku merupakan kata yang berbentuk monomorfemis karena terdiri dari satu morfem saja. Istilah tungku termasuk ke dalam morfem bebas, karena istilah tungku ini dapat berdiri sendiri sebagai sebuah kata tanpa dibantu oleh morfem lain dan tanpa morfem lain istilah tungku ini tetap memiliki arti tersendiri berdasarkan referennya.

Tungku (n) batu tempat tumpuan periuk dan sebagainya waktu memasak (Yos,2015:453). Masyarakat di Kelurahan Karan Aur, masyarakat di Jorong Galagah, Kenagarian Alahan Panjang dan masyarakat di Jorong Silabu, Nagari Parambahan menamakan benda ini dengan nama tungku.

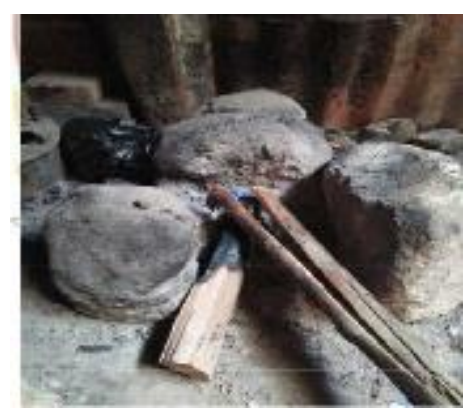

GAMBAR 7. Tungku

Tungku adalah hal yang paling mendasar dan utama yang harus ada dalam dapur tradisional. Dapur tradisional tentu belum dapat berfungsi jika tidak ada tungku di dalamnya. Tungku dibuat secara sederhana dengan menggunakan batu cadas, batu bata ataupun tanah liat, yaitu disusun segitiga ataupun persegi panjang sesuai kebutuhan penggunanya. Tungku merupakan sarana memasak yang menggunakan kayu sebagai bahan bakarnya. Cara memasak menggunakan tungku yaitu dengan cara menyilangkan beberapa potong kayu bakar ke dalamnya, kemudian diberi minyak tanah ataupun benda-benda yang dapat terbakar dengan mudah dan diberi api.

Basilang kayu dalam tungku, disitu api mangko ka iduik (Saydam, 2004: 403) 
Basilang kayu dalam tungku, disitu api mangko ka iduik merupakan salah satu peribahasa yang berkaitan dengan peralatan dapur tradisional, yaitu tungku. Kayu yang bersilang di dalam tungku diibaratkan seperti pendapat yang berbeda antara satu orang dengan yang lainnya. Perbedaan pendapat merupakan suatu yang lumrah terjadi karena melihat permasalahan melalui sisi yang berbeda, yang mana perbedaan pendapat tersebut diselesaikan dengan jalan mufakat sebagai jalan tengahnya.

Mandapek tungku indak barasok (Saydam, 2004: 403)

Mandapek tungku indak barasok merupakan salah satu peribahasa yang berkaitan dengan peralatan dapur tradisional, yaitu tungku. Jika tungku sudah tidak berasap berarti menandakan sebuah rumah yang tidak memiliki bahan makanan untuk dimasak. Peribahasa tersebut berarti tidak mendapat minuman atau makanan ketika bertamu kerumah seseorang.

\section{Baraliah tungku ka halaman}

Baraliah tungku ka halaman merupakan salah satu peribahasa yang berkaitan dengan peralatan dapur tradisional, yaitu tungku. Pada umumnya tungku dibuat dan diletakkan di dapur. Namun pada peribahasa tersebut tungku sudah beralih ke halaman. Peribahasa tersebut diibaratkan kepada seseorang yang bermaksud menyelenggarakan perhelatan biasa membuat dapur darurat di halaman sekitar belakang atau samping rumah karena tungku biasa yang dipergunakan sehari-hari tidak cukup lagi menampung kegiatan dapur.

\section{PENUTUP}

Istilah peralatan dapur tradisional Minangkabau tidak hanya bisa diartikan sebagai sebuah alat atau perangkat memasak. Secara sosial, munculnya leksikon alat dapur dalam ungkapan dan peribahasa menunjukkan keluasan pengetahuan dan wawasan yang berhubungan dengan fungsi material dan kehidupan sosial. Masyarakat Minangkabau khususnya, menggunakan dan memanfaatkan leksikon alat dapur sebagai sarana komunikasi berkias sebagai wujud kuatnya filosofi alam takambang jadi guru.

\section{REFERENSI}

Ayub, Asni dkk. 1993. Tata Bahasa Minangkabau. Jakarta: Departemen Pendidikan dan Kebudayaan. Bapayuang, Yos Magek. 2015. Kamus Baso Minangkabau. Jakarta: Mutiara Sumber Ilmu

Burhanuddin, Erwina. 2009. Kamus Bahasa Minangkabau-Indonesia Balai Bahasa Padang. Padang: Pusat Bahasa Departemen Pendidikan Nasional.

Chaer, Abdul. (2007). Leksikologi dan Leksikografi Indonesia. Jakarta: Rineka Cipta.

Chaer, Abdul. (1995). Pengantar Semantik Bahasa Indonesia. Jakarta: Rineka Cipta.

Djajasudarman, Fatimah. 1999. Semantik 2 Pemahaman Ilmu Makna. Bandung: PT Refika Aditama

Djajasudarman, Fatimah. 1993. Semantik 1 Pengantar Kearah Ilmu Makna. Bandung: PT Eresco anggota IKAPI

Kridalaksana, Harimurti. (2008). Kamus Linguistik. Jakarta: Pt Gramedia Pustaka Utama.

Koentjaraningrat, 1983. Pengantar Ilmu Antropologi. Jakarta: Aksara Baru.

Nafis, Anas. 1996. Peribahasa Minangkabau. Jakarta: Yayasan Dokumentasi dan Informasi Kebudayaan Minangkabau.

Oktavianus.2012. Bertutur Berkias Dalam Bahasa Minangkabau. Padang: Fakultas Ilmu Budaya Universitas Andalas Oktavianus dan Revita Ike. Kesantunan Dalam Bahasa Minangkabau. Padang: Minangkabau Press.

Rohmah, Safrida. 2018. "Istilah Peralatan Rumah Tangga Tradisional di Kabupaten Jepara" dalam 
http://eprints.undip.ac.id/67634/

Saydam, Gouzali. 2004. Kamus Lengkap Bahasa Minang. Padang: Pusat Pengkajian Islam dan Minangkabau (PPIM) Sumatera barat.

Sudaryanto. 1993. Metode dan Aneka Teknik Analisis Bahasa: Pengantar Penelitian Wahana Kebudayaan secara Linguistik

Sudaryat, Yayat. 2009. Makna dalam Wacana. Bandung: Yrama Widya

Sulistya, Andi. 2012. "Isolek Nama Peralatan Rumah Tangga di Kecamatan Binangun Kabupaten Cilacap”. Skripsi. Yogyakarta: Fakultas Bahasa dan Seni Universitas Negeri Yogyakarta.

Wijana, I Dewa Putu.2010. Pengantar Semantik Bahasa Indonesia. Yogyakarta: Program Studi S2 Linguistik Fakultas Ilmu Budaya Universitas Gadjah Mada. 